\author{
Strielkowski, W. ${ }^{1,2}$, and Gryshova, $I^{2}$ \\ ${ }^{1}$ University of California, Berkeley, CA 94720, Berkeley, United States \\ +1(510) 648 3936, strielkowski@berkeley.edu \\ ${ }^{2}$ Center for Scientometrics Research, Prague Business School \\ 29, Werichova, Prague, 152 00, Czech Republic, gryshova@pbs-education.cz
}

\title{
ACADEMIC PUBLISHING AND «PREDATORY» JOURNALS
}

\begin{abstract}
Introduction. Publications in prestigious academic journals have a significant impact on the institutional rankings and help researchers to get grants.

Problem Statement. Nevertheless, the issue of «where» to publish became more important than «what» to publish. The academic race for the higher number of publications led to debates about the phenomenon of the so-called "predatory» journals that publish scientific «rubbish» for money without proper peer review. Purpose. The purpose is to reveal the essence of "predatory» journals and to prove the necessity of indexation as an effective tool for assessing the quality of scientific publications.

Materials and Methods. The ratings of scientific journals and publications in academic journals and «predatory» journals have been compared.

Results. The Czech Republic is one of the countries that seem to be particularly obsessed with the issue of «predatory» journals making a storm in a teacup. According to some estimates, between 2009 and 2013, several Czech universities made around 2 million USD from their researchers their papers and monographs in «predatory» publishing outlets. The case of "predatory» journals was used by some less-productive institutes of the Czech Academy of Sciences to question the system of world's established academic metrics such as Scopus and Web of Science.

Conclusions. All this is possible because currently there are many controversial lists and registries of «predatory» journals, which often contradict each other. However, it appears that indexation of academic journals in Scopus and Web of Science databases is more relevant for their academic worthiness than classifying them in accordance to a plethora of various amateurish lists and blogs.
\end{abstract}

Keywords: academic publishing, bibliometrics, predatory journals, Scopus, and Web of Science.

\section{INTRODUCTION}

Academic publishing is a big business. Large publishing companies make millions on letting the scientists (who are funded by the government) to write and publish their papers in scientific journals that are then sold back to the same scientists in the form of subscriptions and access to the published content [1].

In every country and in every academic community, there is always a plethora of opposing views with regard to how the research should be done and who should be in charge. Science and progress are constantly evolving and dynamic

(C) STRIELKOWSKI, W., and GRYSHOVA, I., 2018 processes and the pressure on academics is getting higher with each year. Hence, the competition is getting tougher too. Recently, the decision «where» to publish becomes more important than «what» to publish for many academics [2].

Open Access (OA) publishing model emerged as the alternative to the large publishing companies that controlled the vast share of the academic publishing market. OA model lets the authors to pay for the publication of their papers once they are peer-reviewed and accepted for publication (so-called «author pays principle»). Immediately, OA became a target of many accusations linking it to the so-called «predatory» journals [3]. 
The term «predatory» journals was coined by Jeffrey Beall, a librarian from the University of Colorado Denver [4]. Although Jeffrey Beall is considered to be an academic expert in questionable publishing practices by many scientists, his list is not officially recognized, by any means, in many countries, for instance in the Czech Republic where the researchers are recently preoccupied by the debates and mutual accusations of «predatory» publishing [5]. This is quite amusing since Beall's List has never been recognized by the Research, Development and Innovation Council of the Czech Republic. The main criterion for judging the academic value of any given publication in this country has always been whether the journal was listed in Scopus or Web of Science.

\section{BEALL'S LIST AND «PREDATORY JOURNALS»}

Even though Jeffrey Beall made quite a career and his list became longer over the years (see Fig. 1), one can see that it is burdened with many controversies and therefore cannot be taken seriously.

Charging a fee does not make a journal «predatory», many reputable journals published by the reputable publishing houses charge publication fees based on their «author pays principle» or offering the authors to grant open access to their published papers (therefore helping to increase downloading and citations) in exchange

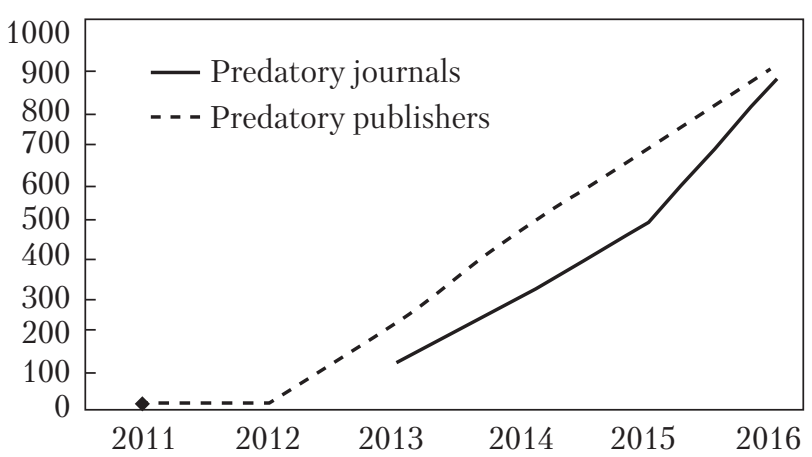

Fig. 1. Increase in journals and publishers marked as «predatory» by Beall's List

Source: [6]. for hefty sums. Additionally, one has to remember that Beall constantly updated his list by adding and removing the journals and publishers from the list. Has anyone decided what to do with the journals and publishers who used to be on Beall's list but were later removed by Beall himself? Or what about the papers published in the journals several years before these very same journals were added to Beall's List? It is now clear how far the indexation should go.

For instance, there a well-known case of MDPI, a publishing house from Switzerland. In 2014, MDPI was added to Beall's list. However, Open Access Scholarly Publishers Association (OASPA) investigation concluded that MDPI met the OASPA membership criteria. Subsequently, MDPI was removed from Mr. Beall's list on October 28, 2015 [7]. Several of MDPI journals currently appear in UK prestigious ABS Academic Journal Guide and in 2017 MDPI partnered with Wiley, Sage, Springer Nature and Cambridge University Press to work on Publons, the new initiative intended to encourage reviewers to peer-review academic papers and earn «publons», or virtual tokens that can be used to assess one's academic performance as a reviewer.

The problematic Beall's List did not survive for long. In January 2017, Jeffrey Beall shut down his blog, removed his list from the Internet and stopped all his online activities altogether (even though he is still invited as a speaker to various conferences on «predatory» publishing, most often to the countries that he used to blame for recognizing the papers published in the «predatory» journals). However, academic publishing became even more difficult without Beall's List. An interesting parallel can be drawn: when Robert James Woolsey took over the Central Intelligence Agency (CIA) in 1993 when the USSR was collapsing, he said, «We have slain a large dragon. But we live now in a jungle filled with a bewildering variety of poisonous snakes. And in many ways, the dragon was easier to keep track of 》 [8]. The same can be said about Beall's List: it 
was troublesome and hardly trustworthy when it existed but the situation became even worse after it is gone [9].

\section{«PREDATORY» PUBLISHING IN THE CZECH REPUBLIC}

The issue of «predatory» journals seems to bother Czech academics more than anyone in the world. The researchers from this small nation seem to be very preoccupied about it. According to the estimates made by Véda žije («Science Lives»), a public initiative, between 2009 and 2013 almost all Czech universities made around USD 2 million from their researchers their papers and monographs in «predatory» publishing outlets [10]. Publishing diploma theses as research monographs with Lambert Academic Publishing, allegedly a «predatory» and «vanity press» outlet, was very popular and some highlyranked university managers even encouraged their students to do so.

Until recently, Czech social scientists did not bother much about publishing in English in top academic journals. Most of them published their research in Czech in local peer-reviewed journals and proceedings. Locally-published books and monographs were considered to be of higher importance for boosting careers and acquiring academic position and degrees. They still are in some fields of the Czech science - for instance, Czech sociologists publish their monographs at Sociologické nakladatelstoí (SLON), a publishing house that is registered in an apartment in a residential building at the outskirts of Prague and features long-deceased academics in its Scientific Board [11].

This situation changed when the focus shifted on publishing in journals listed in Thomson Reuters ISI Web of Knowledge database. In those days, all academic journals listed in this database were considered «prestigious peer-reviewed journals» without distinguishing between their rankings.

In 2013, the situation fundamentally changed when the Research, Development and Innova- tion Council of the Czech Republic adapted its Methodology of Remuneration for Academic Publications in the Czech Republic for 2013-2016. In accordance with the new methodology, the remuneration was conducted based on the points assigned to each publication based on its weight and significance. Publications with an IF and indexed in ISI Web of Knowledge and publications indexed in Scopus gained similar status. For the period of 2013-2016, the formula for attributing the points to the academic publications was set as follows:

$$
\mathrm{Jimp} / \mathrm{sc}=10+295 \times \text { Factor, }
$$

where Factor is the adjusted IF for ISI Web of Knowledge journals, and the SJR for Scopusindexed journals [12].

The methodology is presented in Table that follows. It becomes apparent that the value of Scopus-indexed publications and ISI Web of Knowledge publications has leveled and yields the same output. Moreover, it is also apparent that the value of book chapters and research monographs declined considerably.

Evaluation of the research publications in the Czech Republic (2013-2016)

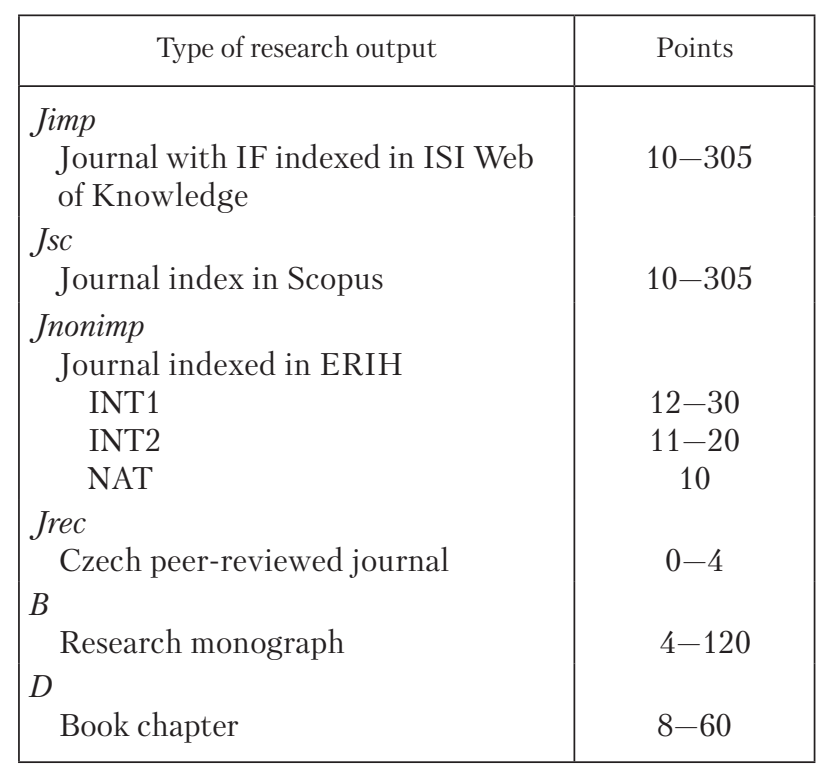

Source: [12]. 
In accordance with the methodology above, Czech academics submit a list of their publications to their Departments or Institutes. The publications are then evaluated at the Department level, then the whole Faculty level, and then submitted via an electronic system to the Central Library (e. g. in the case of the Charles University in Prague) level. The library then compiles the lists and submits them to the Czech Research Evaluation (RIV) submission system.

Each publication is assigned a certain number of points (from 10 to 305). The monetary value of the single point in 2014 was set at about CZK 4000 (about EUR 150) with the decline in subsequent years to CZK 3000 (EUR 110) and lower. Based on these criteria, the monetary reward is calculation for each Czech institution (the money is divided proportionally between the Czech institutions and the foreign co-authors are not rewarded). The money for each publication output goes to the respective institution (University or research institute), where about one half of it is kept at the Rectorate or higher management level for the institutional needs, and the rest goes to the department or the institute where the respective author originates from. The departments and institutes take the money and pay the reward to the authors (quarterly or annually) in accordance with their internal guidelines. In most of the cases, a remuneration for the Scopus-indexed publication would vary between CZK 3000 (EUR 110) and CZK 10000 (EUR 370), while a paper in a journal indexed on Web of Science yielded from CZK 10000 (EUR 370) to CZK 20 000-30 000 (EUR 750-1100).

Hence, the rules are that all publications listed in Scopus and Web of Science databases are rewarded. Moreover, the system of control (which publication gets into the system) is strict and has at least 3 levels of internal control. In addition, it is the university or the research institute that mostly profits from the publications, since the authors receive just a small margin of the money allocated based on the points attributed to their publications [13].
The first explanation might be that the academic job market in the Czech Republic is rigid and the number of posts is limited. Apart from that, a job in the academia does not earn much. In the recent Inomics academic job market report [14] the annual salary of lecturer in the Czech Republic is reported to be under USD 15000 (the same as in Albania or Ukraine). Just for the comparison: the lecturers in the United Kingdom receive USD 47000 a year, while their counterparts in Australia and in the United State earn USD 69000 and USD 76 000, respectively. At the same time, the Czech Republic is one of the few countries where the government pays universities and research institutions for the research output produced by their employees.

The second explanation is that the institution that profited from the debate on the «predatory» journals and pushed hard on escalating this issue is the Czech Academy of Sciences. In 2009, the Czech government wanted to introduce dramatic cuts to the funding of the Academy. The whole situation resulted in massive protests by the employees of the Academy led by the sociologists, philosophers, historians and other social scientists who did not add much to its research publication output. Barricades were built and demonstrations were summoned. The government revoked its decision but introduced a system of funding based on publication outputs in journals listed in Scopus and Web of Science. Now, almost a decade later, it seems that the same people who protested to «save the Czech science» are struggling with the research criteria imposed on them and are looking for ways how to swindle.

A good example of that is Tereza Stöckelová, an Editor-in-Chief of the English edition of the Sociologický časopis (Czech Sociological Review) who publishes in the journal she edits bypassing the peer review and using it for her own agenda for instance, criticizing European Sociological Association for setting up the conference fees for their Prague conference too high or charging an extra 40 EUR for the conference dinner in a luxury restaurant at Vltava River [15]. Another 
example is a «perspective» paper on «predatory» open access publishers that appeared in the Czech journal called Acta Informatica Pragensia in 2015 and was in fact written by the journal's technical editors, Zdeněk Smutný and Václav Řezníček, who also bypassed the peer review to spread their political agenda [16]. All that makes Czech Sociological Review and Acta Informatica Pragensia apt candidates for the inclusions into Beall's List they are defending.

All in all, it becomes clear that many Czech academics are unlikely to survive outside the walls of their universities and research institutions since they have a poor command of English, lack any international experience and thus are unemployable outside (Czech) academia. This is the reason why many people employed in the Czech research institutions are prepared to go to great length to hold on to their jobs. Intrigues, false accusations, involvement of the corrupt journalists in wanted tycoon-owned suspicious mass media - all these become the tools of getting rid of the competition and secure the hefty portion of the academic pie in the Czech on-going «predatory» journals' storm in a teacup.

\section{ALTERNATIVE MEASURES TO TACKLE «PREDATORY» PUBLISHING}

After Beall's List is gone for good and its supporters are left without anything to use in their academic witch hunts, everyone is in search of alternative measures to tackle «predatory» publishing. One of the interesting alternatives is proposed by Cabell's International, a scholarly analytics company from Beaumont, Texas. Not long ago, Cabell's International introduced its new product, the so-called Cabell's Blacklist branding it as the «only blacklist of deceptive and predatory academic journals» [17]. Their Blacklist currently features more than 4000 journals. By emphasizing that their product is the only blacklist, Cabell's International is clearly trying to seize the narrow niche on the tiny market of academic against predatory journals and publishers. The question is, however, whether they would succeed in doing so? Overall, it seems that it would not since Cabell's Blacklist does not seem to be a very good replacement of Beall's List at the moment. We think this is due to a number of reasons: First of all, there is 'an issue of money and pricing. Although the Cabell's Blacklist institutional subscription fee is not that high in comparison with such products at Scopus, ScienceDirect, and Web of Science offered by Elsevier and Clarivate Analytics, it might be a way too pricy for individuals. Beall's List was available free of charge and everyone could check it anytime. Cabell's International is charging hefty sums for their blacklist alternative. According to Cabell's International, the 1-year subscription to its Blacklist can be purchased for $\$ 1500$ add-on cost with purchase of at least one more discipline in Whitelist (ranging from $\$ 1000$ to $\$ 3600$ for one set). Unfortunately, Cabell's International does not provide the users with an opportunity to at least check the free author profile in the same fashion as Scopus, a respected academic database, does.

Second, it is the somewhat misleading metrics used to label a journal as «predatory». Similar to Jeffrey Beall, Cabell's International is undergoing their scrutiny of the journals hidden from the view of the public and announces the results which might be disputed by the publishers and by the academics publishing in the journals that would suddenly appear on the Blacklist.

Third, Cabell's International is trying to play a very dangerous game by extending their scope on all academic journals and not just Open Access ones so fiercely battled against by Jeffrey Beall and his followers. What is going to happen if it will include some journals published by the publishing giants into their Blacklist? In the past, we have already encountered some cases of fake journals (e. g. those sponsored or directly created by the pharmaceutical companies to promote their products via pseudo-scientific papers) published under the umbrella of such prestigious publishers [18]. Jeffrey Beall never dared to face the large publishers and limited his attacks on 
easier targets such as small publishers in places such as Central and Eastern Europe, or Asian countries.

\section{CONCLUSION}

There are many questions left unanswered in the debate about «predatory» journals in academic publishing. For instance, no one has ever given a clear recommendation on what to do about the journals suspected of predatory practices that are indexed in reputable citation databases such as Scopus or the Web of Science. Should we publish in them anyway or should we search for some other lists and publishing ethics committees' guidelines now that Beall is gone? And if so, who will appoint these committees or who will decide which journals are good and which are bad? One can ask, «Quis custodiet ipsos custodes («Who will guard the guardians»)?»

Even though many researchers criticize the uncritical treatment of bibliometrics and developments in «political economy of meta-data» offered by Scopus and Web of Science, they fail to suggest a better alternative. Going away from the world-renowned databases and creating local publication standards might lead to a situation in which a small group of local academics will make decisions on which articles (and which journals) are good and which are bad, and who is going to get a promotion and who is going to be fired. Scopus and Web of Science at least offer some international objectivity.

\section{REFERENCES}

1. Weston, K. (2017). Educating students to play the publication game. Higher Education Research \& Development, 36(5), 1085-1088. URL: https://doi.org/10.1080/07294360.2017.1284034 (Last accessed: 07.10.2017).

2. Brembs, B., Button, K., Munfaro, M. (2013). Deep impact: unintended consequences of journal rank. Frontiers in Human Neuroscience, 7, 291. URL: https://doi.org/10.3389/fnhum.2013.00291 (Last accessed: 07.10.2017).

3. Beall, J. (2015). Predatory journals and the breakdown of research cultures. Information Development, 31(5), 473476. URL: https://doi.org/10.1177/0266666915601421 (Last accessed: 30.09.2017).

4. Beall, J. (2012). Predatory publishers are corrupting open access. Nature, 489(7415), 179. URL: https://doi.org/ 10.1038/489179a (Last accessed: 30.09.2017).

5. Grancay, M., Vveinhardt, J., Sumilo, E. (2017). Publish or perish: how Central and Eastern European economists have dealt with the ever-increasing academic publishing requirements 2000-2015. Scientometrics, 111(3), 1813-1837. URL: https://doi.org/10.1007/s11192-017-2332-z (Last accessed: 30.09.2017).

6. Beall, J. Beall's list of predatory publishers. (2016). URL: https://scholarlyoa.com/2016/01/05/bealls-list-ofpredatory-publishers-2016/ (Last accessed: 07.10.2017).

7. MDPI. Response to Mr. Jeffrey Beall's Repeated Attacks on MDPI. 2014. URL: www.mdpi.com/about/announcement/534 (Last accessed: 07.10.2017).

8. Central Intelligence Agency. Robert James Woolsey's testimony to SSCI, $2^{\text {nd }}$ of February 1993. URL: www.cia.gov/ library (Last accessed: 07.10.2017).

9. Strielkowski, W. (2017). Bell's List is missed. Nature, 544, 416. https://doi.org/10.1038/544416b (Last accessed: 30.09.2017).

10. Věda žije. Vysoké školy čerpaly prostředky z MŠMT za diplomové práce přetištěné jako odborné knihy (Universities received money from the Ministry of Education, Youth and Sport for diploma theses printed as scientific monographs). 2016. URL: http://vedazije.cz/node/5101 (Last accessed: 30.09.2017).

11. SLON. Sociologické nakladatelství. (2017). URL: www.slon-knihy.cz (Last accessed: 30.09.2017).

12. Research, Development and Innovation Council of the Czech Republic. Methodology of remuneration for academic publications in the Czech Republic for the years of 2013-2016. (2013). URL: http://www.vyzkum.cz/FrontClanek. aspx?idsekce=685899. (Last accessed: 02.10.2017).

13. Stöckelová, T., Linková, M. (2012). Public accountability and the politicization of science: The peculiar journey of Czech research assessment. Science and Public Policy, 39(5), 618-629. URL: https://doi.org/10.1093/scipol/scs039 (Last accessed: 30.09 .2017$)$.

14. INOMICS. Job market survey. (2014). URL: www.inomics.com.2014-job-market-survey (Last accessed: 02.10.2017). 
15. Stöckelová, T. (2016). Sociological imagination for Future ESA Conferences. Sociologicky casopis-Czech Sociological Revier, 52(3), 403-404.

16. Smutný, Z., Řezníček, V. (2015). Predatory Open Access Publishers and other Dangers to Today's Scientific Community. Acta Informatica Pragensia, 4(2), 182-200. URL: https://doi.org/10.18267/j.aip.69 (Last accessed: 30.09.2017).

17. Cabell's. The Journal Blacklist. (2017). URL: www.cabells.com/about-blacklist (Last accessed: 06.10.2017).

18. Hutson, S. (2009). Publications of fake journals raises ethnical questions. Nature Medicine, 15, 598. URL: https:// doi.org/10.1038/nm0609-598a (Last accessed: 06.10.2017).

Received 19.10.17

\author{
В. Стріелковскі ${ }^{1,2}$, I. Гришова ${ }^{2}$ \\ ${ }^{1}$ Університет Каліфорния, Берклі, СА 94720, США, \\ +1(510) 648 3936, strielkowski@berkeley.edu \\ ${ }^{2}$ Інститут підвищення кваліфікації, Пражська Бізнес-школа, \\ вул. Веричова, 29, Прага, 152 00, Чешська Республіка, \\ gryshova@pbs-education.cz
}

\title{
АКАДЕМІЧНІ ВИДАННЯ ТА «ХИЖАЦЬКІ» ЖУРНАЛИ
}

Вступ. Публікації в престижних наукових журналах мають суттєвий вплив на рейтинги вищих навчальних закладів та допомагають молодим науковцям отримувати гранти.

Постановка задачі. Академічна гонитва за великою кількістю публікацій призвела до дискусій про феномен так званих «хижих» журналів, які публікують наукове «сміття» за гроші без належного рецензування.

Мета. Розкрити сутність «хижих» журналів та довести необхідність індексації як дієвого інструменту оцінки якості наукових публікацій.

Матеріали й методи. Використано порівняння рейтингів журналів та наукових публікацій в академічних виданнях та «хижих» журналах.

Результати. Чеська Республіка є однією з країн, яка особливо переймається питанням щодо «хижих» журналів. За деякими оцінками, за період 2009-2013 рр. декілька чеських університетів отримали близько 2 мільйонів доларів від публікацій своїх досліджень в газетах та монографіях «хижих» видавництв. Деякі «хижі» журнали використовувалися окремими менш продуктивними інститутами Чеської Академії наук, щоб ставити під сумнів систему світових наукових метрик, таких як Scopus та Web of Science.

Висновки. Все це можливо, тому що на сьогодні існує значна кількість списків та реєстрів «хижих» журналів, які часто суперечать один одному. Проте з'ясовується, що індексація академічних журналів у базах даних Scopus та Web of Science більш актуальна для іххьоої академічної доброчесності, ніж класифікація їх відповідно до безлічі різних аматорських списків та блогів.

Ключові слова: академічна публікація, бібліометрія, «хижі» журнали, Scopus, Web of Science.

\author{
В. Стриелковски ${ }^{1,2}$, И. Гришова ${ }^{2}$ \\ ${ }^{1}$ Университет Калифорния, Беркли, СА 94720, США, \\ +1 (510) 648 3936, strielkowski@berkeley.edu \\ ${ }^{2}$ Институт повышения квалификации, Пражская Бизнес-школа, \\ ул. Веричова, 29, Прага, 152 00, Чешская Республика, \\ gryshova@pbs-education.cz

\section{АКАДЕМИЧЕСКИЕ ИЗДАНИЯ И «ХИЩНЫЕ» ЖУРНАЛЫ}

Введение. Публикации в престижных научных журналах оказывают значительное влияние на рейтинги высших учебных заведений и помогают молодым ученым получать гранты.

Постановка задачи. Академическая гонка за большим количеством публикаций привела к дискуссиям о феномене так называемых «хищных» журналов, публикующих научный «мусор» за деньги без надлежащего рецензирования.

Цель. Раскрыть сущность «хищных» журналов и доказать необходимость индексации как действенного инструмента оценки качества научных публикаций. 
Материалы и методы. Использовано сравнение рейтингов научных журналов и публикаций в академических изданиях и «хищных» журналах.

Результаты. Чешская Республика является одной из стран, которая особенно одержима вопросом о «хищных» журналах. По некоторым оценкам, за период 2009-2013 гг. чешские университеты получили около 2 миллионов долларов от публикаций своих исследований в газетах и монографиях «хищных» издательств. Некоторые из «хищных» журналов использовались отдельными менее производительными институтами Чешской Академии наук, чтобы подвергнуть сомнению систему общемировых академических показателей мира, таких как Scopus и Web of Science.

Выводы. Все это возможно, потому что в настоящее время существует множество списков и реестров «хищных» журналов, которые часто противоречат друг другу. Однако оказывается, что индексация академических журналов в базах данных Scopus и Web of Science более актуальна для их академической значимости, чем классификация в соответствии с множеством разнообразных любительских списков и блогов.

Ключевые слова: академическое издательство, библиометрия, «хищные» журналы, Scopus, Web of Science. 